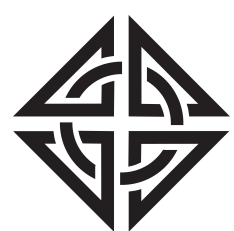

SCIENTIA

I RA N I C A
Sharif University of Technology

Scientia Iranica

Transactions C: Chemistry and Chemical Engineering

www.scientiairanica.com

\title{
Oxidation of $\mathrm{H}_{2} \mathrm{~S}$ to elemental sulfur over alumina-based nanocatalysts: Synthesis and physiochemical evaluations
}

\author{
M. Rezaee ${ }^{a}$, M. Kazemeini ${ }^{a, *}$, M. Fattahi ${ }^{b}$, A.M. Rashidi ${ }^{c}$ and L. Vafajoo $^{\text {d }}$ \\ a. Department of Chemical and Petroleum Engineering, Sharif University of Technology, Tehran, P.O. Box 11155-9465, Iran. \\ b. Department of Chemical Engineering, Abadan Faculty of Petroleum Engineering, Petroleum University of Technology, Abadan, \\ Iran. \\ c. Nanotechnology Research Center, Research Institute of Petroleum Industry (RIPI), Tehran, Iran. \\ d. Chemical and Environmental Engineering Group, Islamic Azad University, Tehran South Branch, Tehran, Iran.
}

Received 3 March 2015; received in revised form 10 August 2015; accepted 16 November 2015
KEYWORDS
$\mathrm{H}_{2} \mathrm{~S}$;
Claus process;
$\mathrm{Al}_{2} \mathrm{O}_{3}$
Spray pyrolysis
method;
Wet chemical
technique;
Nano catalyst.

\begin{abstract}
$\overline{\text { Abstract. In this paper, oxidation of } \mathrm{H}_{2} \mathrm{~S} \text { into elemental sulfur over synthesized alumina- }}$ based nanocatalysts was physiochemically investigated and the results were compared with a commercial Claus catalyst. The wet chemical, co-precipitation, and spray pyrolysis techniques were employed to synthesize several alumina nanostructures. Then, the SEM, $\mathrm{XRD}$, and ASAP analysis methods were utilized to characterize in order to choose the best nanocatalyst. The sulfur and $\mathrm{H}_{2} \mathrm{~S}$ contents were determined through the standard UOP techniques. Amongst the synthesized materials, $\mathrm{Al}_{2} \mathrm{O}_{3}$-supported sodium oxide prepared through the wet chemical, and $\mathrm{Al}_{2} \mathrm{O}_{3}$ nanocatalysts via spray pyrolysis methods were the most active catalysts for the purpose at hand. In addition, the $\mathrm{TiO}_{2}$ nanostructure and a hybrid of nano alumina support (made via the wet chemical method), decorated on the carbon nanotube, were prepared for this goal. Ultimately, the best chemically characterized nanocatalyst was subjected to evaluations in a fixed bed reactor while effects of temperature, metal loading, and GHSV were understudied. It was observed that the alumina nanoparticles prepared through the wet chemical and spray pyrolysis methods led $\mathrm{H}_{2} \mathrm{~S}$ into elemental sulfur in a reproducible manner with 97 and $98 \%$ conversions, respectively. Both of these methods were more desirable than utilizing the commercial catalysts (i.e. CR-3S and CRS-31) providing nearly $96 \%$ conversion.

(C) 2016 Sharif University of Technology. All rights reserved.
\end{abstract}

\section{Introduction}

Hydrogen Sulfide $\left(\mathrm{H}_{2} \mathrm{~S}\right)$ is a highly poisonous and corrosive gas causing serious damages to process equipments. The so called sour gas containing $\mathrm{H}_{2} \mathrm{~S}$ is usually forwarded to a Sulfur Recovery Unit (SRU), through which it is burned into elemental sulfur. There are various methods to remove $\mathrm{H}_{2} \mathrm{~S}$ from gas streams,

*. Corresponding author. Tel.: +98 2166165425

E-mail addresses: kazemini@sharif.edu (M. Kazemeini); moslem.fattahi@gmail.com,fattahi@put.ac.ir (M.Fattahi) including adsorption, direct conversion, and reversible absorption. Moreover, $\mathrm{H}_{2} \mathrm{~S}$ is usually removed by the well-known Claus process in industry. A Claus SRU is considered to be the most common method for conversion of $\mathrm{H}_{2} \mathrm{~S}$ into elemental sulfur for streams possessing high $\mathrm{H}_{2} \mathrm{~S}$ content. The Claus SRU consists of thermal and catalytic segments [1-4]. This process consists of two steps, including thermal oxidation (reaction 1) and catalytic interaction (reaction 2). At the former step, one-third of $\mathrm{H}_{2} \mathrm{~S}$ is initially burned with air into sulfur dioxide in a waste heat furnace. Then, through the latter step, $\mathrm{SO}_{2}$ reacts with unconverted $\mathrm{H}_{2} \mathrm{~S}$ to form 
elemental sulfur over an $\mathrm{Al}_{2} \mathrm{O}_{3}$ catalyst. However, due to the thermodynamic limitations, only $95-97 \%$ of $\mathrm{H}_{2} \mathrm{~S}$ could be converted into sulfur.

$$
\begin{aligned}
& 2 \mathrm{H}_{2} \mathrm{~S}+3 \mathrm{O}_{2} \rightarrow 2 \mathrm{SO}_{2}+2 \mathrm{H}_{2} \mathrm{O}, \\
& 2 \mathrm{H}_{2} \mathrm{~S}+\mathrm{SO}_{2} \rightarrow \frac{3}{n} \mathrm{~S}_{n}+2 \mathrm{H}_{2} \mathrm{O} .
\end{aligned}
$$

In order to increase fractional conversion of $\mathrm{H}_{2} \mathrm{~S}$ to elemental sulfur in comparison with the Claus process, a single step oxidation being practically irreversible with no thermodynamic limitations was developed. Synthesis of active, as well as selective catalysts, was indeed necessary in order to increase conversion of $\mathrm{H}_{2} \mathrm{~S}$ to elemental sulfur. Hence, the most important effective parameters regarding the selection of proper catalysts for a single-step oxidation of $\mathrm{H}_{2} \mathrm{~S}$ had to be considered. Previously, it was demonstrated that the pore size and distribution, particle size and shape, bulk density, mechanical strength, and attrition resistance of the catalyst particles were the main parameters to be considered in such selection [5]. In order to synthesize the most active catalyst for oxidation of $\mathrm{H}_{2} \mathrm{~S}$ to elemental sulfur, catalysts containing vanadium oxide were also utilized both with a stoichiometric and an excess amount of oxygen [6-8]. $\quad \mathrm{VBiO}_{x} / \mathrm{SiO}_{2}$ was used to improve a long-term deactivation problem noticed in $\mathrm{V} / \mathrm{SiO}_{2}$; however, it needed a dehydration step before being sent to a catalytic reactor to increase the $\mathrm{H}_{2} \mathrm{~S}$ conversion [7]. It was suggested that the formation of less active forms of vanadium, such as vanadyl sulfate, was one cause of such deactivation. Yet, various binary oxides, such as V-Sb, V-Mo, V-Mg, $\mathrm{V}-\mathrm{Bi}, \mathrm{Bi}-\mathrm{Mo}$, and $\mathrm{Fe}-\mathrm{Sn}$, were tested in excess oxygen without water by some researchers $[7,8]$. Recently, a $\mathrm{TiO}_{2} / \mathrm{SiO}_{2}$ catalyst with stoichiometric amounts of oxygen demonstrated good activity [3]. The Ce-V mixed oxide with a $\mathrm{V} / \mathrm{Ce}$ atomic ratio of one and with the $\mathrm{CeVO}_{4}$ crystal structure provided very high sulfur selectivity values (i.e. close to one) at almost complete conversion of $\mathrm{H}_{2} \mathrm{~S}$, for $\mathrm{O}_{2} / \mathrm{H}_{2} \mathrm{~S}$ molar ratios close to 0.5 [9]. Moreover, Fe supported on silicon carbide $(\beta$-SiC) showed to be a highly efficient catalyst for the oxidation of $\mathrm{H}_{2} \mathrm{~S}$ into elemental sulfur at reaction temperatures above the sulfur dew point [10].

On the other hand, a dry catalytic process was developed for the selective catalytic oxidation of $\mathrm{H}_{2} \mathrm{~S}$ to elemental sulfur. The commercially developed catalysts for this purpose were of the titanium-based materials in the mobil direct oxidation process (MODOP) and of the iron-based ones in the Super Claus process [11,12]. The vanadium-based mixed oxides [13] and $\mathrm{NaX}-\mathrm{WO}_{3}$ mixtures [14] were also utilized as catalysts for the oxidation of $\mathrm{H}_{2} \mathrm{~S}$ to elemental sulfur. The catalytic performance of vanadia-supported zirconiapillared clay for the selective catalytic oxidation of
$\mathrm{H}_{2} \mathrm{~S}$ was also reported $[15,16]$. Besides, the catalytic performance of Fe-pillared clay and vanadia loaded Fe-pillared clay at temperatures ranging between 220$300^{\circ} \mathrm{C}$ for the selective catalytic oxidation of $\mathrm{H}_{2} \mathrm{~S}$ was studied [17]. The aforementioned catalysts exhibited very good performance in $\mathrm{H}_{2} \mathrm{~S}$ oxidation without much $\mathrm{SO}_{2}$ emission. Furthermore, the $\mathrm{H}_{2} \mathrm{~S}$ conversion increased with enhanced vanadia content up to $7 \mathrm{wt} \%$. This superior catalytic behavior was related to the uniform dispersion of vanadia species provided upon the support [17]. The effect of temperature (in the range of $150-250^{\circ} \mathrm{C}$ ), Gas Hourly Space Velocity (GHSV) (of 2000-4000 $\mathrm{h}^{-1}$ ), and sodium: cadmium weight ratio (of 1-5) over synthesized catalysts of sodium silicate and cadmium oxide supported on silicon carbide nanopowders, on the conversion of $\mathrm{H}_{2} \mathrm{~S}$ to elemental sulfur, was studied by the Box-Behnken experimental design method. Analysis of the experimental data based on the above three effective parameters showed that temperature had the most pronounced effect as an independent variable on the $\mathrm{H}_{2} \mathrm{~S}$ conversion [18]

On the other hand, the direct and selective partial $\mathrm{H}_{2} \mathrm{~S}$ oxidation to elemental sulfur at low temperature might have been an interesting alternative to the traditional methods of $\mathrm{H}_{2} \mathrm{~S}$ abatement if an active and selective catalyst was available. The different type of vanadium-based catalysts supported on the metal oxide $\left(\mathrm{V}_{2} \mathrm{O}_{5}-\mathrm{TiO}_{2}, \mathrm{~V}_{2} \mathrm{O}_{5}-\mathrm{CeO}_{2}, \mathrm{~V}_{2} \mathrm{O}_{5}-\mathrm{CuFe}_{2} \mathrm{O}_{4}\right)$ was performed in the temperature range of $50-250^{\circ} \mathrm{C}$ aiming at high $\mathrm{H}_{2} \mathrm{~S}$ conversion and low $\mathrm{SO}_{2}$ selectivity proved that $\mathrm{V}_{2} \mathrm{O}_{5} / \mathrm{CeO}_{2}$ was a very solid candidate. Based on these results, further investigations into $\mathrm{V}_{2} \mathrm{O}_{5} / \mathrm{CeO}_{2}$ catalyst were performed to study the influence of the inlet concentration of $\mathrm{H}_{2} \mathrm{~S}$ (of 250-1000 ppm), GHSV (of $15000-45000 \mathrm{~h}^{-1}$ ), and molar feed ratio (of $\mathrm{O}_{2} / \mathrm{H}_{2} \mathrm{~S}$ $=0.4-0.5)$ in order to minimize the selectivity of the system towards $\mathrm{SO}_{2}$. The results relevant to the effects of GHSV and the inlet concentrations of $\mathrm{H}_{2} \mathrm{~S}$ showed that these factors did not significantly reduce the $\mathrm{SO}_{2}$ selectivity. Nonetheless, results in terms of $\mathrm{SO}_{2}$ selectivity obtained with a sub-stoichiometric feed ratio $\left(\mathrm{O}_{2} / \mathrm{H}_{2} \mathrm{~S}=0.4\right)$ revealed drastically reduced values from 13 to $4 \%$ without any significant lowering of the $\mathrm{H}_{2} \mathrm{~S}$ or $\mathrm{O}_{2}$ conversions [19].

In the Claus process, alumina $\left(\mathrm{Al}_{2} \mathrm{O}_{3}\right)$ and/or titania $\left(\mathrm{TiO}_{2}\right)$ were employed as the support [3] while $\mathrm{Fe}$, $\mathrm{Co}$, and $\mathrm{Ni}$ were usually the catalytic metals deposited on the aforementioned supports [20,21]. Moreover, alumina was the most common support in conversion of $\mathrm{H}_{2} \mathrm{~S}$ to sulfur. Its strength laid in its potential to disperse active metal catalyst. Indeed, numerous reactions took place between alumina and metal oxide in transition state and some of the produced species were too resistant against sulfidation. This was considered to be a drawback since it lowered activity of the catalyst [22]. $\mathrm{H}_{2} \mathrm{~S}$ oxidation, being highly 
exothermic, caused a major temperature elevation in the catalytic bed, in turn, leading to troublesome hot spots considering the low thermal conductivity of alumina [3]. Ultimately, high temperatures favored the reverse reaction lowering the conversion of $\mathrm{H}_{2} \mathrm{~S}$ to elemental sulfur. Tungsten sulfide catalysts were decorated on single and multi-wall carbon anotubes (SWCNTs \& MWCNTs) and activated carbon was synthesized, characterized, and employed to achieve the conversion of $\mathrm{H}_{2} \mathrm{~S}$ to elemental sulfur. In this regard, a gas flow, containing 5000 ppm of $\mathrm{H}_{2} \mathrm{~S}$ passed over the catalyst under the GHSV of $5000 \mathrm{~h}^{-1}$, temperature of $65^{\circ} \mathrm{C}$, steam volume percent of 20 , and $\mathrm{O}_{2} / \mathrm{H}_{2} \mathrm{~S}$ ratio equal to 2 as the operating conditions, was utilized. The results revealed that the catalyst supported on MWCNTs exhibited higher conversion than its counterparts. Moreover, the effects of GHSV, steam volume percent in the feed, catalyst loading, and temperature for conversion of $\mathrm{H}_{2} \mathrm{~S}$ to elemental sulfur over tungsten sulfide catalyst decorated on MWCNTs were investigated [23].

In the present study, several nanocatalysts were synthesized and their activities were determined. Then, respective values were compared with those of the commercial Claus catalysts. Nano alumina particles were prepared through three methods, including wet chemical, co-precipitation, and spray pyrolysis. In the wet chemical technique, the optimum loading of sodium oxide was determined based upon the Box-Behnken (i.e. the Response Surface Methodology (RSM)) technique. In the spray pyrolysis method, a setup based on the needs of the aforementioned statistical design of experiments was constructed, through which the best alumina-based catalyst with the highest BET surface area for the $\mathrm{H}_{2} \mathrm{~S}$ oxidation was put to test. Beside these, the $\mathrm{TiO}_{2}$ nanoparticles (through hydrolysis and peptization of titanium isopropoxide method [24]) as well as nano hybrid alumina with MWCNT were synthesized and tested in the $\mathrm{H}_{2} \mathrm{~S}$ oxidation setup. Ultimately, it is reiterated that the main goal of the current research was to synthesize new alumina-based nano materials and determine the most active resulting catalyst(s) for the $\mathrm{H}_{2} \mathrm{~S}$ oxidation to elemental sulfur.

\section{Characterization techniques}

The prepared catalysts were characterized by the SEM, XRD, and ASAP analyzer techniques. Scanning Electron Microscopy (SEM) images were obtained with a Philips, XL30 device. Gold meshes were utilized as conductive materials for sample holding. X-Ray Diffraction (XRD) measurements were conducted using standard powder diffraction procedure carried out with a Philips Diffractometer (PW-1840, Lump Cu-k $\mathrm{k}_{\alpha}, \lambda=$ $1.54 \AA)$. The pore size and surface area measurements were performed through a Micromeritics ASAP 2010 instrument by adsorption of nitrogen at $77 \mathrm{~K}$. The sulfur content was determined through a high temperature measurement using IR detector and UOP 864 method with a LECO CS600. $\mathrm{H}_{2} \mathrm{~S}$ concentration was analyzed using a Mettler potentiometer (DL $70 \mathrm{ES}$ ) with an accuracy of $\pm 1 \%$ of $\pm 1 \mathrm{~mL}$ equipped with an $\mathrm{Ag}-\mathrm{Ag}_{2} \mathrm{~S}$ electrode (DM 141-SC) and the UOP-163 methods with detection threshold of $0.5 \mathrm{ppm}$. Product stream was passed through a $25 \mathrm{wt} . \% \mathrm{KOH}$ solution at regular time intervals of $10 \mathrm{~min}$ to measure its $\mathrm{H}_{2} \mathrm{~S}$ content.

\section{Catalyst preparation}

Several nanocatalysts were synthesized and each one was tested through the $\mathrm{H}_{2} \mathrm{~S}$ oxidation setup designed and constructed in this research to find the most active material. The methods of nanocatalyst preparation and the performed characterizations are described below.

\subsection{Preparation of nano alumina}

The nano alumina was prepared through three methods. First, in the wet chemical method at $55^{\circ} \mathrm{C}, 5.0 \mathrm{~g}$ of $\mathrm{AlCl}_{3} \cdot 6 \mathrm{H}_{2} \mathrm{O}(97 \%$ supplied by the Aldrich Chemical) was dissolved into $325 \mathrm{~mL}$ of distilled water. A mixture of $5.0 \mathrm{~g}$ of ammonia and $2.0 \mathrm{~g}$ of sorbitol was added, dropwise, to the first solution. The sorbitol acted as surfactant, utilized to accelerate the precipitation. The desired $\mathrm{pH}$ value of 10-10.5 for the solution was reached through adding $\mathrm{NH}_{4} \mathrm{OH}$ to the mixture in order to observe a white precipitate. Then, temperature of this solution rose to $70^{\circ} \mathrm{C}$ under vigorous stirring and insulation with aluminum foil. The resulting precipitate was left under vigorous agitation for $10 \mathrm{~min}$ and then filtered and washed to get neutralized. This precipitate was washed with a solution of $100 \mathrm{~mL}$ ethanol and $100 \mathrm{~mL}$ distilled water. It was then dried at $60^{\circ} \mathrm{C}$ for $24 \mathrm{~h}$ and calcined at $600^{\circ} \mathrm{C}$ for $4 \mathrm{~h}$ to get the $\gamma-\mathrm{Al}_{2} \mathrm{O}_{3}$. The XRD pattern and SEM images of materials made through this method were presented in a previous publication of this research team [25]. It was inferred that the prepared particles were almost spherical, smooth, non-aggregated, and relatively uniform in size, being of nano-scale (i.e. $<100 \mathrm{~nm})$.

Second, in the co-precipitation method, $5.0 \mathrm{~g}$ of $\mathrm{AlCl}_{3} \cdot 6 \mathrm{H}_{2} \mathrm{O}$ was dissolved into $325 \mathrm{~mL}$ of distilled water at $55^{\circ} \mathrm{C}$. Then, according to stoichiometry of sodium carbonate with $\mathrm{AlCl}_{3} \cdot 6 \mathrm{H}_{2} \mathrm{O}$, based on Eq. (3), $3.3 \mathrm{~g}$ of sodium carbonate was dissolved into the minimum amount of distilled water at $50^{\circ} \mathrm{C}$. Next, sorbitol was added to this solution and the resulting mixture was added, dropwise, to the first solution. Afterward, temperature of the final solution rose to $70^{\circ} \mathrm{C}$ and it was kept there for 10 min under vigorous 


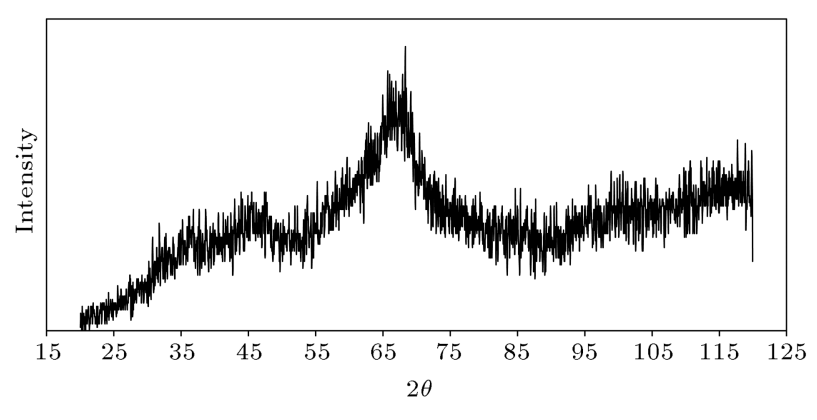

Figure 1. The XRD patterns of the prepared alumina nanoparticles through the co-precipitation method.

stirring while being insulated with the aluminum foil. Next, it was filtered and washed such that its $\mathrm{pH}$ was adjusted to a value of $8-9$. Then, the precipitate was dried at $60^{\circ} \mathrm{C}$ for $24 \mathrm{~h}$ and calcined at $600^{\circ} \mathrm{C}$ for $4 \mathrm{~h}$ to ultimately result in the $\gamma-\mathrm{Al}_{2} \mathrm{O}_{3}$ material.

$$
\begin{aligned}
2 \mathrm{AlCl}_{3} \cdot 6 \mathrm{H}_{2} \mathrm{O} & +3 \mathrm{Na}_{2} \mathrm{CO}_{3} \rightarrow 6 \mathrm{NaCl}+\mathrm{Al}_{2}\left(\mathrm{CO}_{3}\right)_{3} \\
& +6 \mathrm{H}_{2} \mathrm{O}
\end{aligned}
$$

The powder XRD results obtained for these $\mathrm{Al}_{2} \mathrm{O}_{3}$ nanoparticles are presented in Figure 1. Two peaks at $2 \theta=47^{\circ}$ and $2 \theta=67-68^{\circ}$ were observed. The first peak was related to the sodium oxide $\left(\mathrm{Na}_{2} \mathrm{O}\right)$. However, since most of the sodium was washed away during the alumina synthesis, its peak was rather weak, while the second peak, related to $\gamma-\mathrm{Al}_{2} \mathrm{O}_{3}$, was more pronounced.

Another technique, through which the alumina nanoparticle was synthesized, was the spray pyrolysis technique. Spray pyrolysis technique was based on the ultrasonic generation of micro-sized aerosol droplets and their decomposition at intermediate temperatures $\left(400-800^{\circ} \mathrm{C}\right)$. Due to the fact that evaporation, precipitation, drying, and decomposition occurred in a dispersed phase and at a single step, it became possible to control important particle properties such as size, morphology, and chemical composition simply by controlling the process parameters. Such parameters included the residence time and decomposition temperature. Unlike many other film deposition techniques, spray pyrolysis represented a very simple and relatively cost-effective processing method [26-28]. In the present set-up, a pressure nozzle and a static mixer were utilized for generation of micrometric-size aerosol droplets. The spray pyrolysis experimental set-up is shown in Figure 2. In all experiments, two equimolar solutions of $\mathrm{Al}\left(\mathrm{NO}_{3}\right)_{3} .9 \mathrm{H}_{2} \mathrm{O},(99.997 \%$ purity, supplied by the Aldrich Chemicals) and sodium carbonate $\left(\mathrm{Na}_{2} \mathrm{CO}_{3} 99.99 \%\right.$, supplied by the Merck Chemicals) were mixed in the static mixer and then through using a pressure nozzle sprayed into the reactor. Nitrogen was used as a carrier gas with pressure kept at 2 bar. The particles were water-collected at the reactor exhaust. The XRD pattern of the as-

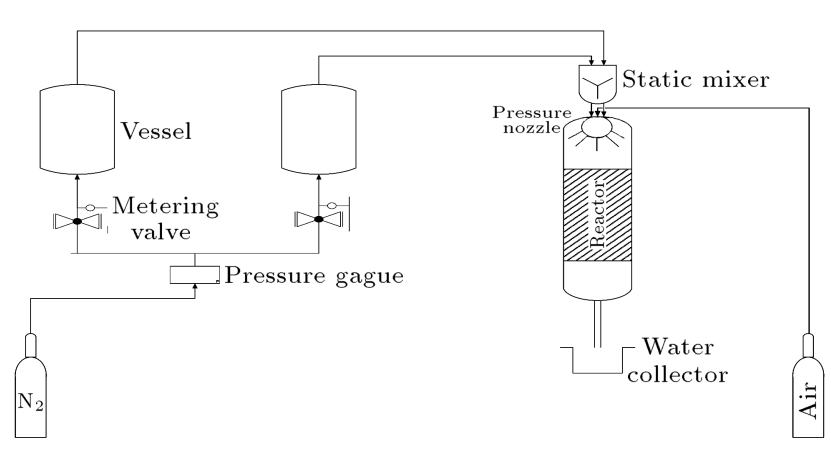

Figure 2. Schematic representation of the spray pyrolysis technique for synthesizing alumina nanoparticles.

prepared catalyst was revealed in a previous work by the authors [25]. The XRD pattern of the best sample of the $\mathrm{Al}_{2} \mathrm{O}_{3}$ nanoparticles, produced through this method, possessed the highest BET surface area. This was provided in third row of Table 1 . Once again, in previous investigation by this research group into this material [25], a weak peak at $2 \theta=47^{\circ}$ indicated the existence of sodium oxide, while the next peak at $2 \theta=67-68^{\circ}$ was related to $\gamma-\mathrm{Al}_{2} \mathrm{O}_{3}$, the material sought in this work.

\subsection{Preparation of titanium dioxide}

Titanium oxide nanoparticles were prepared by hydrolysis and peptization of titanium isopropoxide (TTIP) solution. In this method, $5 \mathrm{~mL}$ of TTIP (97\% purity supplied by the Aldrich Chemical) was dissolved in $15 \mathrm{~mL}$ of isopropanol (99\% purity provided by the Merck Chemicals) without heating. Then, the $\mathrm{pH}$ of $250 \mathrm{~mL}$ distilled water was reduced by the concentrated nitric acid solution to a value of about 2 and was added dropwise to the first solution under vigorous agitation in order to produce a gel. In other words, a turbid solution due to hydrolysis of the TTIP was obtained. This turbid solution was heated to 60$70^{\circ} \mathrm{C}$ for almost $18-20 \mathrm{~h}$ when peptization occurred. After the peptization process, the volume of solution decreased to $50 \mathrm{~mL}$ and an opaque suspension was obtained. The obtained precipitation was washed (to prevent agglomeration) with ethanol, dried in a vacuum system for several hours at $100^{\circ} \mathrm{C}$ and calcined at $200^{\circ} \mathrm{C}$ for $2 \mathrm{~h}$ to get anatase phase of titanium oxide. It should be noted that the anatase phase was formed at $200^{\circ} \mathrm{C}$ while rutile phase formed at $800^{\circ} \mathrm{C}$ and the phase transition occurred at $600^{\circ} \mathrm{C}$. Further details of the hydrolysis method for producing $\mathrm{TiO}_{2}$ nanoparticles were available in the open literature [24]. The powder XRD and SEM of this material are presented in Figures 3 and 4, respectively. The XRD results obtained for the $\mathrm{TiO}_{2}$ nanoparticles revealed a peak at $2 \theta=54-55^{\circ}$ displaying highly crystalline material while emphasizing anatase phase formation. The SEM micrograph reconfirmed the nanostructure of the obtained $\mathrm{TiO}_{2}$. 
Table 1. Design matrix and experimental data of the alumina synthesis with spray pyrolysis method used in this study.

\begin{tabular}{|c|c|c|c|c|}
\hline \multirow[b]{2}{*}{$\begin{array}{c}\text { Experiment } \\
\text { no. }\end{array}$} & \multicolumn{3}{|c|}{ Independent parameters } & \multirow{2}{*}{$\begin{array}{c}\text { Dependent parameter } \\
\text { Response: } \\
\text { aBET } \\
\left(\mathrm{m}^{2} / \mathrm{g}\right) \\
\end{array}$} \\
\hline & $\begin{array}{c}\text { A: Temperature } \\
\left({ }^{\circ} \mathrm{C}\right)\end{array}$ & $\begin{array}{c}\text { B: Solution } \\
\text { concentration } \\
(\mathrm{mol} / \mathrm{L})\end{array}$ & $\begin{array}{c}\text { C: Flowrate } \\
(\mathrm{mL} / \mathrm{min})\end{array}$ & \\
\hline 1 & 650 & 0.05 & 110 & 369 \\
\hline 2 & 500 & 0.15 & 110 & 188 \\
\hline 3 & 650 & 0.1 & 70 & 395 \\
\hline 4 & 650 & 0.1 & 150 & 215 \\
\hline 5 & 575 & 0.05 & 150 & 246 \\
\hline 6 & 500 & 0.05 & 110 & 128 \\
\hline 7 & 575 & 0.1 & 110 & 190 \\
\hline 8 & 500 & 0.1 & 150 & 210 \\
\hline 9 & 575 & 0.15 & 70 & 222 \\
\hline 10 & 575 & 0.05 & 70 & 233 \\
\hline 11 & 500 & 0.1 & 70 & 199 \\
\hline 12 & 650 & 0.15 & 110 & 160 \\
\hline 13 & 575 & 0.1 & 110 & 195 \\
\hline 14 & 575 & 0.15 & 150 & 203 \\
\hline
\end{tabular}

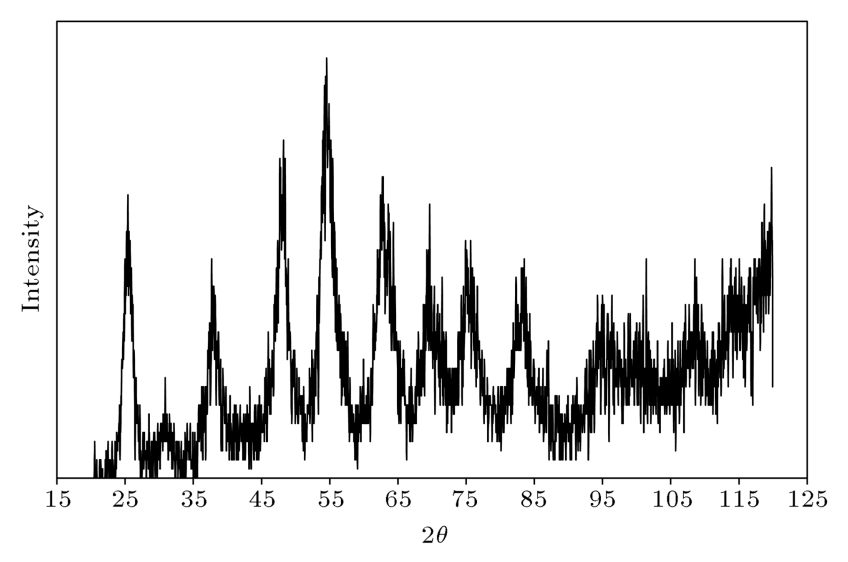

Figure 3. The XRD pattern of the prepared titanium oxide nanoparticle.

\subsection{Preparation of hybrid $M W C N T$ and alumina}

The MWCNT prepared over the Co-Mo/MgO catalysts was previously prepared by this research group. This was done through different organic additives using a modified sol-gel method through a Chemical Vapor Deposition (CVD) reactor [29]. The same materials were also utilized in the present research. The carbon nanotubes (CNT) used in this work were meshed in the range of 100 to 120 (i.e. 125 to $149 \mu \mathrm{m}$ ).

For synthesizing $\mathrm{Al}_{2} \mathrm{O}_{3}-\mathrm{CNT}$ with $\mathrm{Al}_{2} \mathrm{O}_{3}$ to $\mathrm{CNT}$ weight ratio equal to one, the alumina nano-particle catalysts were prepared by the wet chemical method. Then, $1.1 \mathrm{~g}$ of CNT (i.e., based upon calculating the mass of alumina in the $\mathrm{AlCl}_{3} \cdot 6 \mathrm{H}_{2} \mathrm{O}$ material), synthesized at the final stage of preparation, was added to the solution. Next, temperature of solution was

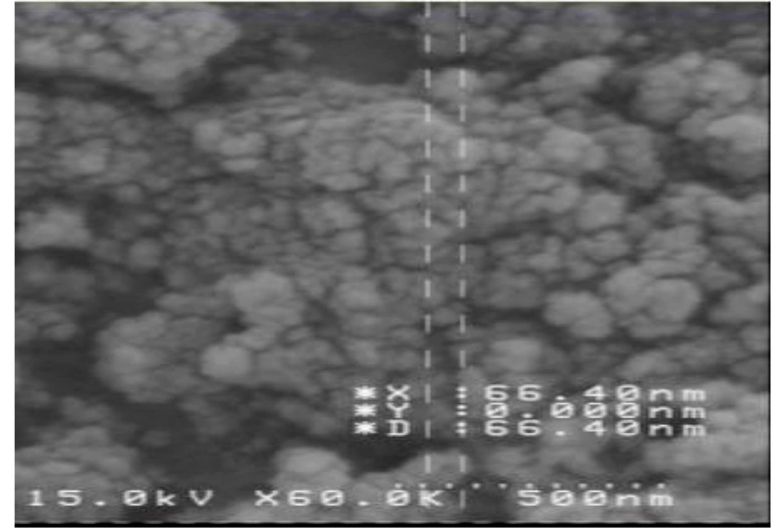

Figure 4. The SEM micrograph of the synthesized titanium oxide nanoparticle.

raised to $70^{\circ} \mathrm{C}$ under vigorous stirring while being insulated with aluminum foil. The resulting precipitate was left under vigorous agitation for $10 \mathrm{~min}$, then filtered and washed to get neutralized. Then, $100 \mathrm{~mL}$ of distilled water was mixed with $100 \mathrm{~mL}$ of ethanol and simultaneously poured over the precipitate. The resulting material was dried at $60^{\circ} \mathrm{C}$ for $24 \mathrm{~h}$ and calcined at $450^{\circ} \mathrm{C}$ for $4 \mathrm{~h}$ to produce the desired catalyst. At temperatures greater than $450^{\circ} \mathrm{C}$, the CNT was oxidized; hence, the calcination occurred under a neutral atmosphere. Figures 5 and 6 demonstrate the powder XRD pattern and SEM image of $\mathrm{Al}_{2} \mathrm{O}_{3}$-MWCNT nanohybrid particles. Several peaks, especially at $2 \theta=40-41^{\circ}$, were observed in this pattern indicating existence of the MWCNT as well as the amorphous alumina. From the SEM micrograph of Figure 6, the mean diameter of these nanoparticles 


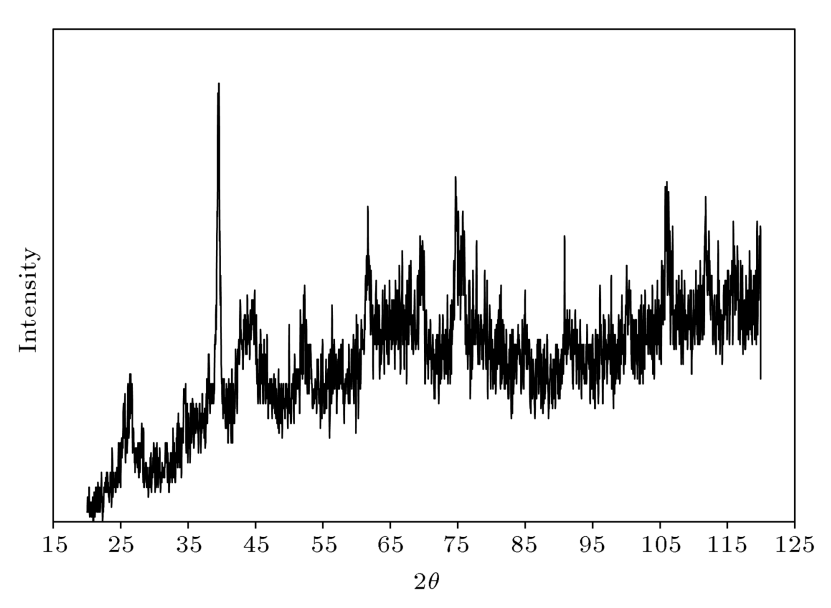

Figure 5. The powder XRD pattern of the prepared hybrid of $\mathrm{Al}_{2} \mathrm{O}_{3}-\mathrm{MWCNT}$ in this work.

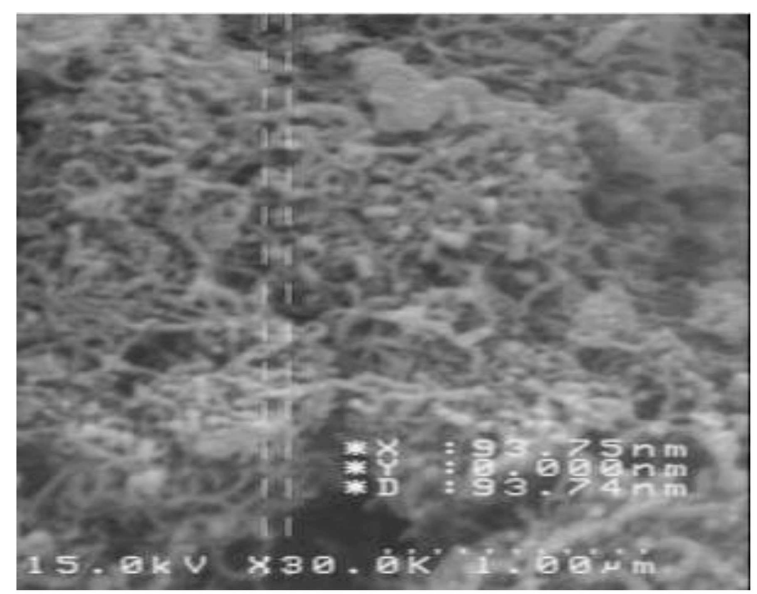

Figure 6. The SEM micrograph of the prepared hybrid of $\mathrm{Al}_{2} \mathrm{O}_{3}$-MWCNT in this research.

was estimated to be lower than $100 \mathrm{~nm}$, which was in good agreement with the previously determined XRD results.

\section{4. $\mathrm{H}_{2} \mathrm{~S}$ experimental rig}

A schematic flow diagram of the catalytic oxidation process is shown in Figure $7 . \mathrm{H}_{2} \mathrm{~S}$ oxidation was carried out under isothermal condition and atmospheric pressure. The fixed-bed reactor was constructed by a stainless steel-316 tube of $12.5 \mathrm{~mm}$ ID and $450 \mathrm{~mm}$ length. The gas mixture was passed downwards through the catalytic bed. The reactor was vertically placed in an electrical furnace of which the temperature was controlled by a thermal indicator. The flow rates of the gases (i.e. $\mathrm{O}_{2}, \mathrm{He}, \mathrm{H}_{2} \mathrm{~S}$ ) were monitored and controlled with Bronkhorst mass flow meters linked to JUMO (d-TRON 304) electronic control units. The catalyst was heated from room temperature to the reaction temperature with slope of $5^{\circ} \mathrm{C} / \mathrm{min}$ in the presence of helium. At this point, the reactant started flowing into the reactor.

\section{Results and discussion}

RSM is considered to be a practical and easy way to optimize a given process based upon the experimental data [30,31]. In the current study, Design Experts Software (Version 8.0.1) was employed for designing experiments, mathematical modeling, and optimization. To obtain rational results by the RSM, three steps ought to be considered. The first one, in a successful RSM optimization, is to design the experiments for evaluating the model parameters, efficiently. The second step is to develop a polynomial model fitted to the experimental data through regression and then to check suitability of the model by applying a statistical test (e.g., lack-of-fit, F-test) [31-33]. The third and final stage is to determine the value of factors satisfying the optimum conditions. Usually, a first- or secondorder polynomial might be used for the RSM analysis. Furthermore, for responses possessing a curvature, a second-order polynomial is preferred. The linear form of such polynomial would be as follows:

$$
y=\beta_{0}+\sum_{i=1}^{k} \beta_{i} x_{i}+\sum_{i=1}^{k} \sum_{\substack{j=1 \\ i<j}}^{k} \beta_{i j} x_{i} x_{j}+\varepsilon,
$$

where, $y$ is the predicted response, $\beta_{0}$ a constant, $\beta_{i}$ the $i$ th linear coefficient, $\beta_{i j}$ the $i$ th interaction coefficient, $x_{i}$ the independent variable, $k$ the number of factors, and $\varepsilon$ the associated error. In addition, the coefficients of the model are predicted through regression. Details of the parameter estimations for such a model have been reported in [31].

\subsection{Affecting parameters for synthesizing of $\mathrm{Al}_{2} \mathrm{O}_{3}$ nanoparticles through the spray pyrolysis method}

Statistical design of experiments, namely, the RSM method, was utilized in order to screen effects of the significant synthesis parameters in spray pyrolysis. Efficient response resulting in the maximum BET surface area required early identification of the key process parameters. Through the spray pyrolysis method, based on the literature [34,35], the following optimization variables were considered:

(i) Temperature;

(ii) Concentration of solution;

(iii) Flow rate of air.

These varied in ranges of $500-650^{\circ} \mathrm{C}, 0.05-0.15 \mathrm{~mol} / \mathrm{L}$, and $70-150 \mathrm{~mL} / \mathrm{min}$, respectively. The RSM design may find the influences of each process variable versus variation of others as well as the interactions amongst these variables on the synthesis of alumina nanoparticles. Three level designs with 3 key variables were sought in this study. Therefore, the total runs were 


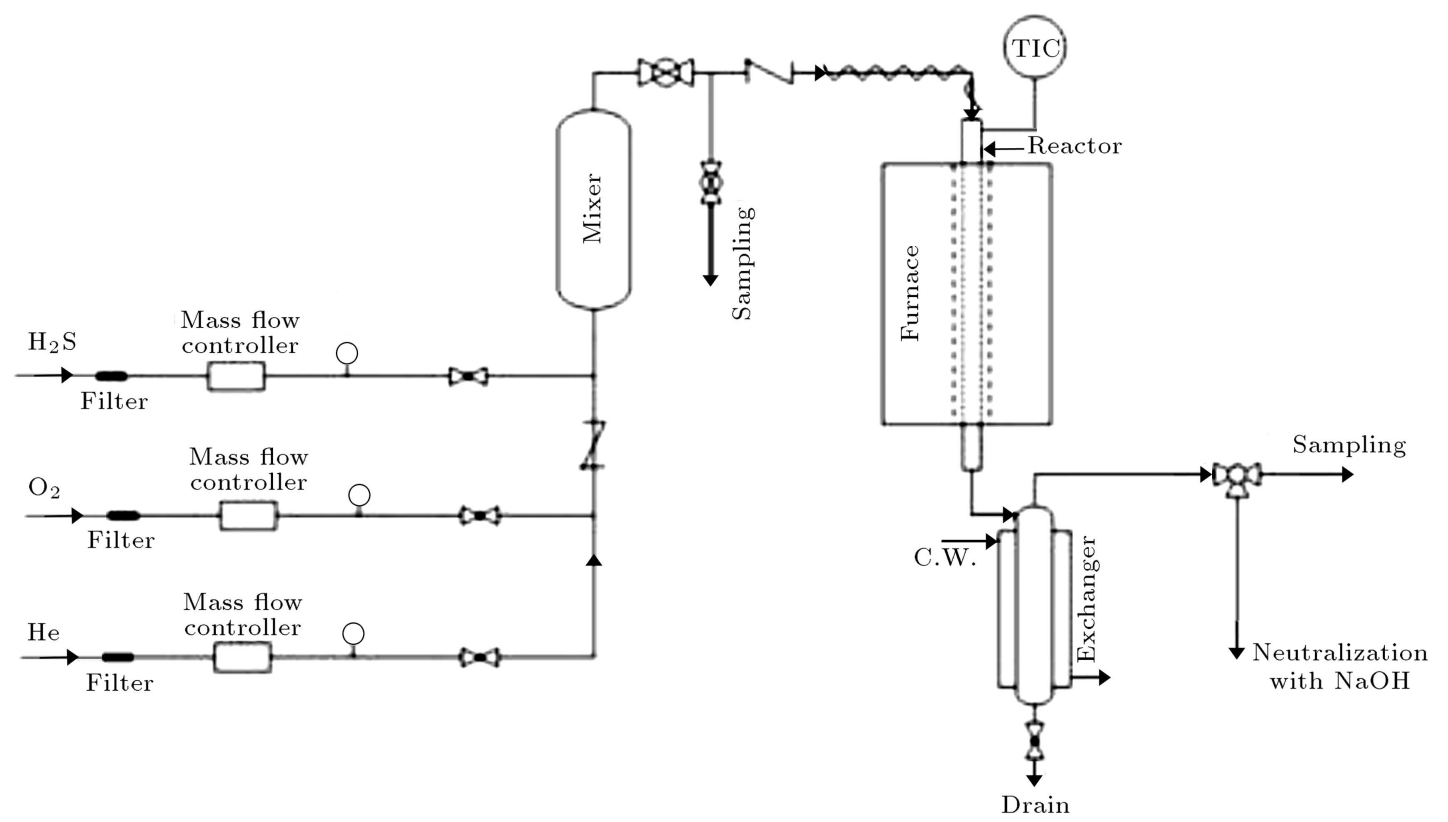

Figure 7. Schematic diagram of the $\mathrm{H}_{2} \mathrm{~S}$ oxidation rig utilized in the present study.

limited to 14 . Hence, 14 tests, according to Table 1 , were performed and for each one, the BET surface area was measured.

Effects of the following process variables on the synthesis of alumina nanoparticles were investigated through the aforementioned design study: (a) temperature, (b) concentration of solution, and (c) the flow rate. The fixed levels of these three variables are provided in Table 2. The analysis of variance (ANOVA) in the synthesis of alumina nanoparticles is summarized in Table 3. The $F$-test statistics were defined as $F$

Table 2. Factors and levels for the Box-Behnken design.

\begin{tabular}{ccccc}
\hline Factor & Variable & \multicolumn{3}{c}{ Level } \\
\hline A & $\begin{array}{c}\text { Temperature }\left({ }^{\circ} \mathrm{C}\right) \\
\text { B }\end{array}$ & 500 & 575 & 650 \\
& $\begin{array}{c}\text { Solution concentration } \\
(\mathrm{mol} / \mathrm{L})\end{array}$ & 0.05 & 0.10 & 0.15 \\
$\mathrm{C}$ & Flowrate $(\mathrm{mL} / \mathrm{min})$ & 70 & 110 & 150 \\
\hline
\end{tabular}

Table 3. ANOVA for the synthesis of alumina nanoparticle by the experimental design.

\begin{tabular}{cccccc}
\hline Factor & DF & SS & MS & F & P \\
\hline A & 1 & 21424.5 & 21424.5 & 13.80 & 0.008 \\
B & 1 & 5151.1 & 5151.1 & 3.31 & 0.112 \\
C & 1 & 3828.1 & 3828.1 & 2.46 & 0.161 \\
AB & 1 & 18090.3 & 18090.2 & 11.63 & 0.011 \\
AC & 1 & 9120.3 & 9120.2 & 5.86 & 0.046 \\
BC & 1 & 256.0 & 256.0 & 0.16 & 0.697 \\
Error & & 12.5 & & & \\
Total & & 68762.4 & & & \\
\hline
\end{tabular}

$=\mathrm{MSF} / \mathrm{MSE}$, in which the MSF and MSE were the mean squares of factors (or interactions) and errors, respectively. If the calculated value of $F$ was greater than the value in the $F$-test at a specified probability level, a statistically significant factor or interaction was determined. From a combination of estimates for the process variables and the ANOVA results, a linear model with statistical significance might had been generated. The related model in this research, quantitatively elucidating the effects of process variables with statistical significance, was presented as follows:

Surface area $=-2142.53+4.23 \mathrm{~A}-17.93 \mathrm{AB}$

$$
-0.02 \mathrm{AC} \text {. }
$$

The statistical importance of the generated model was evaluated via the Fisher test (i.e. $F$-test) and quantified by dividing the model mean square by its residual mean square for ANOVA. The results of ANOVA are presented in Table 4.

Based upon the $F$ value presented in Table 4, being greater than 2.7, and the adequate precision value of 8.5 (being greater than 4 ), the proposed model was determined to be adequately satisfactory over more than $95 \%$ of the significant data compared to those available in the open literature [36]. As may be seen from Table 4 for the response, the p-value related to the lack of fit test was smaller than 0.05, emphasizing this to be significant as well.

The 3-D curves related to the impact of the independent variables of temperature, concentration, and flow rate were demonstrated on the BET surface area in Figure 8(a)-(c). As shown in Figure 8(a), 


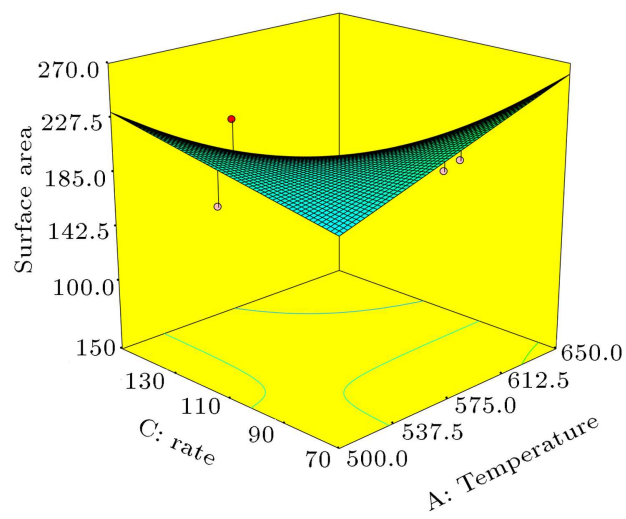

(a) Concentration $=0.15 \mathrm{M}$

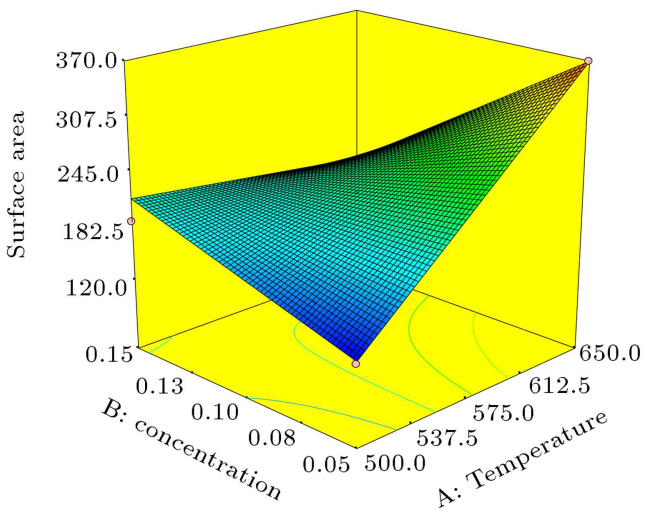

(b) Flowrate=110 $\mathrm{Ml} / \mathrm{min}$

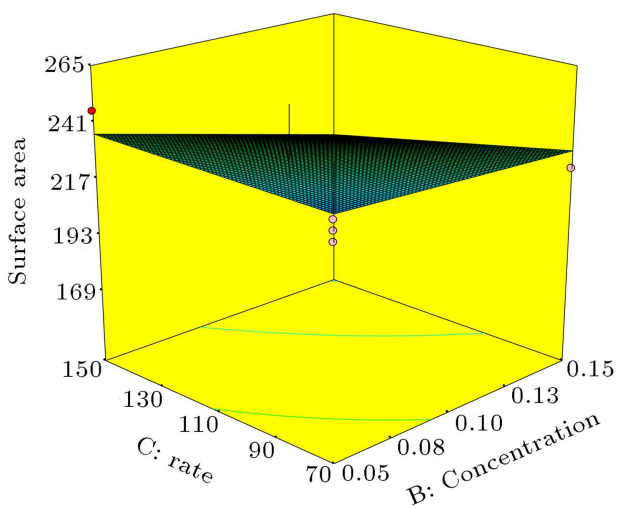

(c) $\mathrm{T}=575^{\circ} \mathrm{C}$

Figure 8. 3-D plot effects of temperature, concentration, and flow rate on the specific surface area.

Table 4. ANOVA for the linear model proposed in the present work.

\begin{tabular}{lc}
\hline Parameters of the model & Value \\
\hline Sum of Squares (SS) & 57870.3 \\
Degree of Freedom (DF) & 6.0 \\
Mean Square (MS) & 9645.0 \\
$F$ value & 6.2 \\
$p$-value probability $>F$ & 0.02 \\
Standard deviation & 39.5 \\
Mean & 225.2 \\
Coefficient of Variation $(\mathrm{CV})$ & 17.5 \\
$R^{2}$ & 0.8 \\
Adj.- $R^{2}$ & 0.7 \\
Pre.- $R^{2}$ & 0.3 \\
Adequate precision & 8.5 \\
\hline
\end{tabular}

enhancing the temperature, at lower flow rates, resulted in increased specific surface area. However, at higher flow rates, lowering of the specific surface area was the outcome. On the other hand, at a fixed concentration, with increasing the flow rate, the effect of temperature on the specific surface area was less pronounced; whereas at lower flow rates, the effect of temperature on the specific area was significant. Figure 8(a) also indicates the effects of flow rate on specific surface area as a function of temperature. From this figure, it is observed that increasing the flow rate at higher temperatures leads to a decreased specific surface area since the feed residence time in the reactor is lowered. As such, the reaction is rendered incomplete, resulting in a lowered specific surface area.

Figure 8(b) demonstrates that with increased concentration at higher temperatures, the specific surface area decreases due to coagulation of the particles, leading to occurrence of the major extent of the reaction in the bulk of the solution. Furthermore, from this figure, it is seen that the influence of concentration, as the temperature swings from lower to higher values, becomes considerably less pronounced. Finally, Figure $8(\mathrm{c})$ reveals that the concentration and flow rate do not have any sensitive interactions.

From Figure $8(\mathrm{a})-(\mathrm{c})$, it is observed that at higher temperatures, increasing the concentration values causes the reduction of the surface area and vice versa. As seen from Figure 8(b), at higher temperatures, increased concentration lowers the surface area of alumina particles while at lower temperatures, increased concentration enhances the BET surface area of the alumina particles. This emphasizes that there 
was an optimum concentration for the purpose at hand.

\subsection{Screening the parameter affecting synthesized nano-alumina catalysts}

Based on previous studies [9,37-39] undertaking the $\mathrm{H}_{2} \mathrm{~S}$ removal, the optimization process variables in the present work included: (i) temperature, (ii) metal loading, and (iii) GHSV. They were varied in the ranges of $200-300^{\circ} \mathrm{C}, 0.2-1.6 \%$, and $5500-7500 \mathrm{~h}^{-1}$, respectively. In all the experiments, concentration of $\mathrm{H}_{2} \mathrm{~S}$ in feed gas was fixed at $6.6 \%$, equivalent to concentration of $\mathrm{H}_{2} \mathrm{~S}$ at the first Claus convertor. Moreover, $\mathrm{O}_{2} / \mathrm{H}_{2} \mathrm{~S}$ ratio equaled to the stoichiometric value $\left(\mathrm{O}_{2} / \mathrm{H}_{2} \mathrm{~S}=\right.$ $0.5)$ in all runs. In all experiments, $6 \mathrm{~mL}$ of catalyst with mesh of $80-200 \mu \mathrm{m}$ was used. Steady state conversion was obtained after $6 \mathrm{~h}$ of experiment. In order to investigate the interactions, the three-level Box-Behnken design with the abovementioned three key variables was developed. Therefore, once again, the total runs were limited to 14 . The fixed levels of the three operating variables are provided in Table 5. The observation of the fractional conversion of $\mathrm{H}_{2} \mathrm{~S}$

Table 5. Factors and levels for the 3-level Box-Behnken designed in this work.

\begin{tabular}{clccc}
\hline \multirow{2}{*}{ Factor } & \multirow{2}{*}{ Variables } & \multicolumn{3}{c}{ Level } \\
\cline { 3 - 5 } & & $\mathbf{- 1}$ & $\mathbf{0}$ & $\mathbf{1}$ \\
\hline A & Temperature $\left({ }^{\circ} \mathrm{C}\right)$ & 200 & 250 & 300 \\
B & Metal loading $(\%)$ & 0.2 & 0.9 & 1.6 \\
$\mathrm{C}$ & GHSV $\left(\mathrm{h}^{-1}\right)$ & 5500 & 6500 & 7500 \\
\hline
\end{tabular}

to sulfur through the design matrix is revealed in Table 6 .

Data of the fractional conversion of $\mathrm{H}_{2} \mathrm{~S}$ to sulfur is shown in Table 6. It was subjected to regression analysis to estimate the effects of process variables. The ANOVA results of the fractional conversion of $\mathrm{H}_{2} \mathrm{~S}$ to sulfur are summarized in Table 7 . If the calculated value of $F$ was greater than that obtained in Table 7 , at a specified probability level, a statistically significant factor or interaction was obtained. In the present case, $\mathrm{A}, \mathrm{C}, \mathrm{AB}, \mathrm{AC}, \mathrm{A}^{2}$ and $\mathrm{C}^{2}$ were determined as significant model terms. From a combination of estimates for the process variables and the ANOVA results, a quadratic polynomial model with statistical

Table 7. ANOVA for the fractional conversion of $\mathrm{H}_{2} \mathrm{~S}$ to sulfur through the experimental design.

\begin{tabular}{ccccc}
\hline Factor & DF & SS & MS & $\boldsymbol{F}$ \\
\hline $\mathrm{A}$ & 1 & 248.55 & 248.55 & 63.34 \\
$\mathrm{~B}$ & 1 & 1.37 & 1.37 & 0.35 \\
$\mathrm{C}$ & 1 & 87.77 & 87.77 & 22.37 \\
$\mathrm{AB}$ & 1 & 182.25 & 182.25 & 46.44 \\
$\mathrm{AC}$ & 1 & 225 & 225 & 57.33 \\
$\mathrm{BC}$ & 1 & 23.52 & 23.52 & 5.99 \\
$\mathrm{~A}^{2}$ & 1 & 147.42 & 147.42 & 37.57 \\
$\mathrm{~B}^{2}$ & 1 & 19.4 & 19.4 & 4.94 \\
$\mathrm{C}^{2}$ & 1 & 33.02 & 33.02 & 8.42 \\
Error & & 2 & & \\
Total & & 921.68 & & \\
\hline
\end{tabular}

Table 6. Design matrix for the fractional conversion of $\mathrm{H}_{2} \mathrm{~S}$ to elemental sulfur by the experimental design in this research.

\begin{tabular}{|c|c|c|c|c|}
\hline \multirow[b]{2}{*}{ Run no. } & \multicolumn{3}{|c|}{ Independent variables } & \multirow{2}{*}{$\begin{array}{c}\text { Dependent variable } \\
\text { Response: } \\
\text { Conversion } \\
(\text { mol. \%) } \\
\end{array}$} \\
\hline & $\begin{array}{c}\text { A: Temperature } \\
\left({ }^{\circ} \mathrm{C}\right)\end{array}$ & $\begin{array}{c}\text { B: Metal } \\
\text { loading } \\
(\%)\end{array}$ & $\begin{array}{c}\text { C: GHSV } \\
\left(h^{-1}\right)\end{array}$ & \\
\hline 1 & 250 & 0.2 & 5500 & 94.8 \\
\hline 2 & 250 & 0.9 & 6500 & 97 \\
\hline 3 & 250 & 0.9 & 7500 & 81 \\
\hline 4 & 200 & 0.9 & 7500 & 71 \\
\hline 5 & 200 & 0.2 & 5500 & 96 \\
\hline 6 & 250 & 1.6 & 7500 & 90 \\
\hline 7 & 250 & 0.2 & 5500 & 95.5 \\
\hline 8 & 300 & 0.9 & 6500 & 99 \\
\hline 9 & 250 & 0.2 & 6500 & 95 \\
\hline 10 & 200 & 0.9 & 6500 & 76 \\
\hline 11 & 300 & 0.9 & 7500 & 91 \\
\hline 12 & 300 & 0.9 & 5500 & 86 \\
\hline 13 & 200 & 1.6 & 6500 & 88 \\
\hline 14 & 300 & 1.6 & 6500 & 84 \\
\hline
\end{tabular}




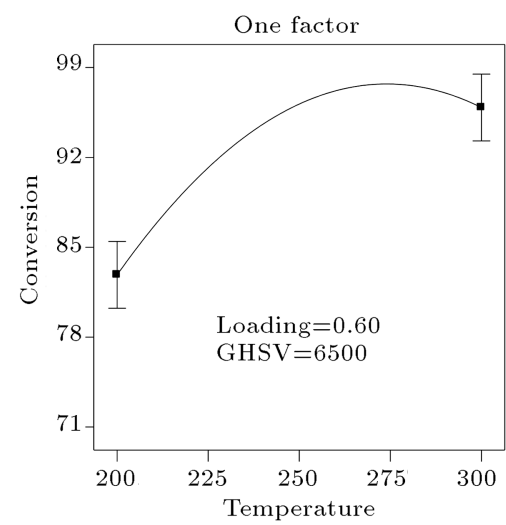

(a)

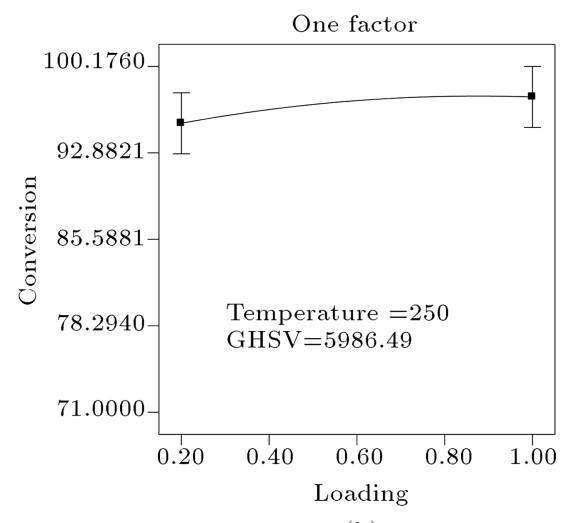

(b)

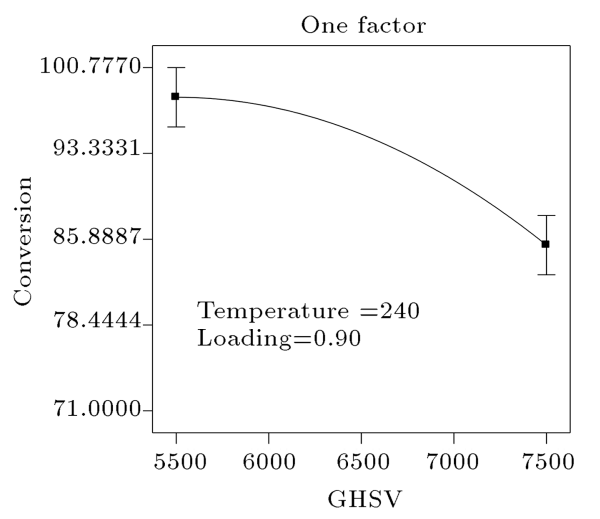

(c)

Figure 9. Main effects of (a) reaction temperature, (b) loading, and (c) GHSV on the conversion of $\mathrm{H}_{2} \mathrm{~S}$ to sulfur.

significance was generated. This model quantitatively elucidated the effects of process variables with statistical significance as follows:

Fractional conversion of $\mathrm{H}_{2} \mathrm{~S}=-17.77290$

$$
\begin{aligned}
& +0.62857 \times T+2.46786 \times 10^{-3} \times \mathrm{GHSV} \\
& -0.19286 \times T \times \text { Loading }+1.5 \times 10^{-4} \times T \\
& \times \mathrm{GHSV}-3.46429 \times 10^{-3} \times \text { Loading } \times \mathrm{GHSV} \\
& -2.71500 \times 10^{-3} \times T^{2}-5.02551 \times \text { Loading }^{2} \\
& -3.21250 \times 10^{-6} \times \mathrm{GHSV}^{2} .
\end{aligned}
$$

In Eq. (6), the terms without statistical significance were deleted from the full effect model, based upon the ANOVA. These effects were considered to be errors in the experiments and their variances were accordingly pulled into the Sum of Squares of Errors (i.e. SSE). Therefore, the multiple correlation coefficient squared, $R^{2}=1$-(SSE/SST), equal to 0.983 , indicated a very good fitting to the experimental data of fractional conversion on factors $\mathrm{A}, \mathrm{B}$, and $\mathrm{C}$ (Table 8). The main

Table 8. The ANOVA for the proposed model.

\begin{tabular}{lc}
\hline Parameters of the model & Value \\
\hline Sum of Squares (SS) & 905.99 \\
Degree of Freedom (DF) & 9 \\
Mean Square (MS) & 100.67 \\
$F$ value & 25.65 \\
Standard deviation & 1.98 \\
Coefficient of Variation $(\mathrm{CV})$ & 2.23 \\
$R^{2}$ & 0.983 \\
Adj.- $R^{2}$ & 0.945 \\
Pre.- $R^{2}$ & 0.754 \\
Adequate precision & 17.067 \\
\hline
\end{tabular}

effects (i.e. A, B, and C) and two-factor interactions effects (i.e. $\mathrm{AB}$ and $\mathrm{AC}$ ) for fractional conversion of $\mathrm{H}_{2} \mathrm{~S}$ to sulfur are shown in Figure 9, respectively. Here, the two upper and lower limits of conversion, as a function of dependent variables, were emphasized while the behavioral trends between them were predicted through the presented software.

From Figure 9(a), the fractional conversion of $\mathrm{H}_{2} \mathrm{~S}$ to sulfur is increased by increasing temperature up to about $265^{\circ} \mathrm{C}$; however, it decreases when increasing temperature from 265 to $300^{\circ} \mathrm{C}$. At lower values, the enhancement of temperature leads to increase in the rate of reaction; hence, the redox ability of the catalyst rises. This causes fractional conversion of $\mathrm{H}_{2} \mathrm{~S}$ to elemental sulfur to increase as well. Of course, some $\mathrm{SO}_{2}$ formation during the reaction predicted through Eqs. (7) and (8) is possible:

$$
\begin{aligned}
& \frac{1}{n} \mathrm{~S}_{n}+\mathrm{O}_{2} \rightarrow \mathrm{SO}_{2}, \\
& 2 \mathrm{H}_{2} \mathrm{~S}+3 \mathrm{O}_{2} \rightarrow 2 \mathrm{SO}_{2}+2 \mathrm{H}_{2} \mathrm{O} .
\end{aligned}
$$

Nonetheless, it is obvious that the $\mathrm{SO}_{2}$ formation caused a decrease in the sulfur selectivity; because of using stoichiometric ratio of $\mathrm{O}_{2} / \mathrm{H}_{2} \mathrm{~S}$, there was no $\mathrm{SO}_{2}$ formation in the system, even at higher temperatures. This was another reason for decreasing conversion at temperatures higher than $265^{\circ} \mathrm{C}$. Decrease in conversion of $\mathrm{H}_{2} \mathrm{~S}$ to sulfur might have been partly due to the changes in surface properties of $\mathrm{Na}_{2} \mathrm{O} / \mathrm{Al}_{2} \mathrm{O}_{3}$ nanocatalyst at a higher temperature. At temperatures over $265^{\circ} \mathrm{C}$, a very sharp decrease in $\mathrm{H}_{2} \mathrm{~S}$ conversion was observed within the first few minutes of the reaction, and then, the conversion values became stable. This sharp decrease was observed during the first few minutes of the reaction, indicating a change in the surface properties of the catalyst, including decrease in surface area, pore diameter, and volumes, as well as aggregation of the active sites at temperatures beyond $265^{\circ} \mathrm{C}$. From Figure $9(\mathrm{~b})$, the fractional conversion of 
Table 9. Porosimetry and surface area results of synthesized nanoparticles in this research.

\begin{tabular}{|c|c|c|c|c|}
\hline Sample & $\begin{array}{c}A_{s}(\text { BET }) \\
\left(\mathrm{m}^{2} / \mathrm{g}\right)\end{array}$ & $\begin{array}{c}\text { Total pore } \\
\text { volume } \\
\left(\mathrm{cm}^{3} / \mathrm{g}\right)\end{array}$ & $\begin{array}{c}\text { Mean pore } \\
\text { diameter } \\
(\mathbf{n m})\end{array}$ & $\begin{array}{c}\boldsymbol{R}_{p, \text { peak }} \\
(\mathbf{n m})\end{array}$ \\
\hline $\mathrm{Al}_{2} \mathrm{O}_{3}$ (wet chemical) & 278.24 & 0.72 & 10.31 & 1.66 \\
\hline $\mathrm{TiO}_{2}$ & 169.34 & 0.13 & 3.11 & 1.22 \\
\hline $\mathrm{Al}_{2} \mathrm{O}_{3}+\mathrm{CNT}$ & 268.00 & 0.35 & 4.65 & 1.66 \\
\hline $\mathrm{Al}_{2} \mathrm{O}_{3}$ (spray method) & 395.00 & 0.74 & 11.52 & 1.62 \\
\hline
\end{tabular}

$\mathrm{H}_{2} \mathrm{~S}$ to sulfur is increased by increasing loading up to about $0.9 \%$, and from 0.9 to $1.6 \%$, it is decreased. At lower loadings, the quantity of the active phase was lower; however, by increasing the metal loading, the ability of the catalyst for oxidation of $\mathrm{H}_{2} \mathrm{~S}$ became higher, meaning that the conversion to elemental sulfur was expected to rise. On the other hand, using nanocatalyst instead of conventional ones caused reactant to be trapped and also led to an increase in partial pressure of this species, in turn, enhancing oxidation of $\mathrm{H}_{2} \mathrm{~S}$ to sulfur. Nevertheless, there was the possibility of occurrence of catalyst pore blockage at higher loadings; hence, $\mathrm{H}_{2} \mathrm{~S}$ conversion lowered. Figure $9(\mathrm{c})$ reveals that the fractional conversion of $\mathrm{H}_{2} \mathrm{~S}$ to sulfur was increased by decreasing the GHSV. By increasing the GHSV, residence time decreased such that enough time for complete reaction was not allowed; thus, the conversion decreased. Although by lowering the GHSV, conversion increased, in an industrial Claus process, due to the corrosiveness of $\mathrm{H}_{2} \mathrm{~S}$, indeed such operating conditions was not desirable. Thus, at a low temperature, high GHSV and low metal loading extent and high and desired conversion might be obtained.

It was clear from Table 7 that interactions $\mathrm{AB}$ and $\mathrm{AC}$ were more significant than others confirmed through the $F$-test value. It was interesting, however, to note that only the interaction $\mathrm{AC}$ was highly significant according to the $F$-test value. At constant GHSV, by increasing temperature, conversion enhanced. From the above results and discussion, the key variables affecting the fractional conversion of $\mathrm{H}_{2} \mathrm{~S}$ to sulfur might have been easily identified by means of the statistically experimental methodology.

For the present research, the optimum values were found to be: temperature $=222^{\circ} \mathrm{C}, \mathrm{GHSV}=5591 \mathrm{~h}^{-1}$, and loading $=1.23 \mathrm{wt} \%$. This set gave the highest predicted $\mathrm{H}_{2} \mathrm{~S}$ conversion of $99.5 \%$ for the optimized response. It is revealed that the optimized temperature value leaned toward its lower limit (in comparison with Claus conventional reactors) in order to boost conversion of $\mathrm{H}_{2} \mathrm{~S}$ to sulfur. Furthermore, as an added advantage, optimizing the GHSV to such a high value might lead to alleviation of the corrosive effects of $\mathrm{H}_{2} \mathrm{~S}$ on the mechanical instruments.

\section{Comparison between the commercial Claus catalyst and the synthesized nanocatalysts}

From the ASAP analyzer outcome (see Table 9), one might have concluded that the alumina nanoparticles, prepared through the wet chemical and spray pyrolysis methods, resulted in high BET surface areas and total pore volume as compared to other synthesized materials in this study, therefore, leading to higher conversions to elemental sulfur. It is observed that a decrease in the total pore volume, synonymous to an increase in the mass transfer resistance, ended up in a BET surface area reduction, which, in turn, resulted in a lowered reactivity of the nanocatalyst. Moreover, the results of the ASAP analyzer revealed that the surface area of the used catalyst after the reaction at $300^{\circ} \mathrm{C}$ was $230 \mathrm{~m}^{2} / \mathrm{g}$, being about $20 \%$ less than that of the fresh catalyst (i.e. it was $287.24 \mathrm{~m}^{2} / \mathrm{g}$ ), emphasizing the provided rationale.

An alumina-based (CR-3S) and a titania-based Claus catalyst (CRS-31) were tested in $\mathrm{H}_{2} \mathrm{~S}$ oxidation setup at Claus operating conditions [40]. Specifications of these Claus catalysts are provided in Table 10. Experiments were performed at temperature of $250^{\circ} \mathrm{C}$, pressure of $1 \mathrm{~atm}, 12-14$ mesh size of catalyst $(1.3 \mathrm{~mm})$, $\mathrm{GHSV}=5500 \mathrm{~h}^{-1}, \mathrm{O}_{2} / \mathrm{H}_{2} \mathrm{~S}=0.5$, and $6.6 \% \mathrm{H}_{2} \mathrm{~S}$ in the feed stream. In addition, synthesized nanoparticles were tested and fractional conversions were calculated for each one. Instantaneous fractional conversion of $\mathrm{H}_{2} \mathrm{~S}$ is defined as follows:

$$
\text { Conversion of } \mathrm{H}_{2} \mathrm{~S}(\%)=\frac{\left[\mathrm{H}_{2} \mathrm{~S}\right]_{\text {in }}-\left[\mathrm{H}_{2} \mathrm{~S}\right]_{\text {out }}}{\left[\mathrm{H}_{2} \mathrm{~S}\right]_{\text {in }}} \times 100 \text {. }
$$

$\mathrm{H}_{2} \mathrm{~S}$ concentration was calculated through utilizing a Mettler potentiometer with detection threshold of $0.5 \mathrm{ppm}$ :

$$
\operatorname{ppm~} \mathrm{H}_{2} \mathrm{~S}=\frac{16000 \times N_{\mathrm{Ag}^{+}} \times V_{\mathrm{Ag}^{+}}}{M},
$$

where, $N_{\mathrm{Ag}}^{+}$was normality of $\mathrm{AgNO}_{3}$ solution; $V_{\mathrm{Ag}}^{+}$, the volume consumed; and $M$, the molecular weight of gas sample.

Steady state conversion, demonstrated in Figure 10, was obtained after $6 \mathrm{~h}$ for nanoparticles 
Table 10. Commercial Claus catalyst specifications [40].

\begin{tabular}{|c|c|c|c|}
\hline \multirow[t]{2}{*}{ Physical properties } & \multirow[t]{2}{*}{ Unit } & \multicolumn{2}{|c|}{ Typical value } \\
\hline & & CR-3S & CRS-31 \\
\hline Bulk density & $\mathrm{kg} / \mathrm{m}^{3}$ & 660 & 1000 \\
\hline Surface area (BET) & $\mathrm{m}^{2} / \mathrm{g}$ & 320 & 130 \\
\hline \multirow[t]{4}{*}{ Porosity (macro-porosity) } & $\mathrm{mL} / \mathrm{g}$ & 0.2 & - \\
\hline & & \multicolumn{2}{|c|}{ Chemical analysis } \\
\hline & & $\mathrm{Al}_{2} \mathrm{O}_{3}>93.8 \%$ & $\mathrm{TiO}_{2}>85 \%$ \\
\hline & & $\mathrm{Na}_{2} \mathrm{O} 2000 \mathrm{ppm}$ & \\
\hline
\end{tabular}

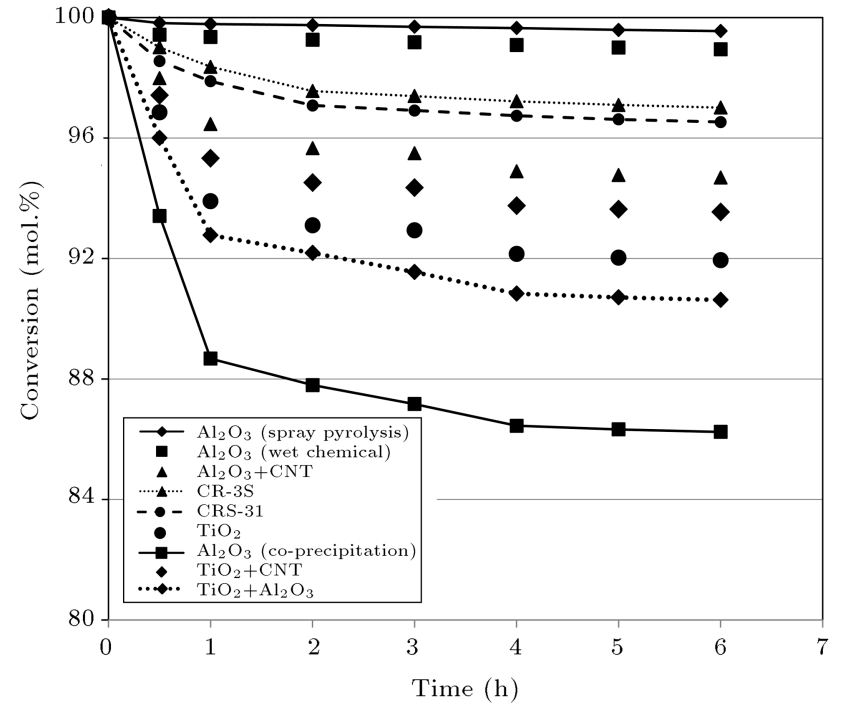

Figure 10. The fractional conversion of $\mathrm{H}_{2} \mathrm{~S}$ to elemental sulfur over synthesized nanocatalyst and commercial Claus catalysts (reaction conditions: $T=250^{\circ} \mathrm{C}, P=1 \mathrm{~atm}$, $12-14$ mesh of catalyst $(1.30 \mathrm{~mm}), \mathrm{GHSV}=5500 \mathrm{~h}^{-1}$, $\mathrm{O}_{2} / \mathrm{H}_{2} \mathrm{~S}=0.5$, and $6.6 \% \mathrm{H}_{2} \mathrm{~S}$ in the feed stream).

prepared in this research. It is reiterated that each conversion to elemental sulfur was performed 3 times and an average value for each point is presented in this figure. This emphasizes the reproducibility of the data. It was observed that, amongst materials prepared in this study, alumina nanoparticles prepared through the wet chemical and spray pyrolysis methods had higher activities and resulted in higher conversions than that of the commercial Claus catalyst. Because the reaction between $\mathrm{H}_{2} \mathrm{~S}$ and $\mathrm{O}_{2}$ was irreversible, no thermodynamic restrictions existed; hence, conversions higher than 95-97\% (usually obtained for the commercial catalysts) were achieved.

Furthermore, the total sulfur analysis of the Claus commercial conventional catalyst and the synthesized nanocatalyst after reaction at $250^{\circ} \mathrm{C}$, GHSV $=5500 \mathrm{~h}^{-1}, \mathrm{O}_{2} / \mathrm{H}_{2} \mathrm{~S}=0.5$, and $6.6 \% \mathrm{H}_{2} \mathrm{~S}$ in the feed stream is summarized in Table 11 . It is seen that the synthesized nanocatalyst in this research had more sulfur adsorbed on its surface. In industry, removal of $\mathrm{H}_{2} \mathrm{~S}$ and converting it into elemental sulfur are usually
Table 11. Total sulfur analysis of Claus commercial catalyst and synthesized alumina nanoparticles with wet chemical method in this work.

\begin{tabular}{lc}
\hline \multicolumn{1}{c}{$\begin{array}{c}\text { Sample } \\
\text { name }\end{array}$} & $\begin{array}{c}\text { Weight } \\
\text { percent of } \\
\text { sulfur (\%) }\end{array}$ \\
\hline $\begin{array}{l}\text { Commercial catalyst } \\
\text { Alumina nanoparticles } \\
\text { synthesized with wet } \\
\text { chemical method in this work }\end{array}$ & 3.02 \\
\hline
\end{tabular}

performed either by the thermal or catalytic techniques possessing 3-5 steps. However, the system with catalysts developed in the current research included only one fixed bed reactor. It was shown to be capable of higher interactions of $\mathrm{H}_{2} \mathrm{~S}$ on the surface of the developed catalyst, resulting in higher conversions into elemental sulfur.

Ultimately, the reactor test results along with the porosimetric properties of materials, understudied in this work, made it clear that the larger pore volumes and higher surface areas were definitely desired for obtaining a better performing catalyst to produce elemental sulfur from $\mathrm{H}_{2} \mathrm{~S}$.

\section{Conclusions}

The successful application of the statistical design approach to experiments for the optimization of oxidation of $\mathrm{H}_{2} \mathrm{~S}$ was reported in this research. The wet chemical, co-precipitation, and spray pyrolysis methods were selected for synthesis of the alumina nanostructures utilized in this work. The results showed that the $\mathrm{Al}_{2} \mathrm{O}_{3}$ prepared with the wet chemical and spray pyrolysis methods provided effective catalysts for the oxidation of $\mathrm{H}_{2} \mathrm{~S}$ to elemental sulfur under Claus operating conditions. In other words, high values $(>98 \%)$ of the $\mathrm{H}_{2} \mathrm{~S}$ conversion to elemental sulfur in a reproducible manner were obtained for these materials. For the $\mathrm{H}_{2} \mathrm{~S}$ removal, three factors affecting catalyst performances were identified and optimized using the Box-Behnken design technique. It was demonstrated that the factors of temperature and GHSV had more 
pronounced effects on the conversion of $\mathrm{H}_{2} \mathrm{~S}$ to elemental sulfur than others. Furthermore, a sodium oxide supported alumina nanocatalyst provided total sulfur conversion (near $100 \%$ ) in the oxidation of $\mathrm{H}_{2} \mathrm{~S}$ with a feed stream containing stoichiometric amounts of oxygen and $\mathrm{H}_{2} \mathrm{~S}$.

Reaction tests and catalyst characterization using XRD, SEM, and ASAP analyzer techniques showed that the surface behavior of the nanocatalyst changed during the reaction such that at higher temperatures, catalysts were deactivated perhaps due to faster poisoning attributed to the sulfide layer and sulfate formation on the surface of these materials. Moreover, it was shown that temperature was the most important operating variable such that at low to intermediate values, the highest conversion of $\mathrm{H}_{2} \mathrm{~S}$ to elemental sulfur was reported. Ultimately, it was demonstrated that utilizing catalysts developed through this study, a single-stage fixed bed reactor was sufficient to provide a high conversion of $\mathrm{H}_{2} \mathrm{~S}$ to elemental sulfur as compared to the Claus conventional catalyst in a multistage process.

\section{References}

1. Tasdemir, H.M., Yasyerli, S. and Yasyerli, N. "Selective catalytic oxidation of $\mathrm{H}_{2} \mathrm{~S}$ to elemental sulfur over titanium based Ti-Fe, Ti-Cr and Ti-Zr catalysts", International Journal of Hydrogen Energy, 40(32), pp. 9981-10001 (2015).

2. Kim, M.-I., Ju, W.-D., Kim, K.-H., Park, D.-W. and Hong, S.-S. "Selective oxidation of hydrogen sulfide to elemental surfur and ammonium thiosulfate using $\mathrm{VO}_{x} / \mathrm{TiO}_{2}$ catalysts", Studies in Surface Science and Catalysis, 159, pp. 225-228 (2006).

3. Chun, S.W., Jang, J.Y., Park, D.W., Woo, H.C. and Chung, J.S. "Selective oxidation of $\mathrm{H}_{2} \mathrm{~S}$ to elemental sulfur over $\mathrm{TiO}_{2} / \mathrm{SiO}_{2}$ catalysts", Applied Catalysis B: Environmental, 16, pp. 235-243 (1998).

4. Elsner, M.P., Menge, M., Müller, C. and Agar, D.W. "The Claus process: teaching an old dog new tricks", Catalysis Today, 79-80, pp. 487-494 (2003).

5. ZareNezhad, B. "An investigation on the most important influencing parameters regarding the selection of the proper catalysts for Claus SRU converters", Journal of Industrial and Engineering Chemistry, 15, pp. 143-147 (2009).

6. Shin, M.Y., Nam, C.M., Park, D.W. and Chung, J.S. "Selective oxidation of $\mathrm{H}_{2} \mathrm{~S}$ to elemental sulfur over $\mathrm{VO}_{x} / \mathrm{SiO}_{2}$ and $\mathrm{V}_{2} \mathrm{O}_{5}$ catalysts", Applied Catalysis $A$ : General, 211, pp. 213-225 (2001).

7. Li, K.-T., Huang, M.-Y. and Cheng, W.-D. "Vanadium-based mixed-oxide catalysts for selective oxidation of hydrogen sulfide to sulfur", Industrial \& Engineering Chemistry Research, 35, pp. 621-626 (1996).
8. Li, K.-T., Yen, C.-S. and Shyu, N.-S. "Mixed-metal oxide catalysts containing iron for selective oxidation of hydrogen sulfide to sulfur", Applied Catalysis A: General, 156, pp. 117-130 (1997).

9. Yasyerli, S., Dogu, G. and Dogu, T. "Selective oxidation of $\mathrm{H}_{2} \mathrm{~S}$ to elemental sulfur over $\mathrm{Ce}-\mathrm{V}$ mixed oxide and $\mathrm{CeO}_{2}$ catalysts prepared by the complexation technique", Catalysis Today, 117, pp. 271-278 (2006).

10. Nguyen, P., Edouard, D., Nhut, J.-M., Ledoux, M.J., Pham, Ch. and Pham-Huu, C. "High thermal conductive $\beta$-SiC for selective oxidation of $\mathrm{H}_{2} \mathrm{~S}$ : A new support for exothermal reactions", Applied Catalysis B: Environmental, 76, pp. 300-310 (2007).

11. Park, D.-W., Hwang, B.-H., Ju, W.-D., Kim, M.-I., Kim, K.-H. and Woo, H.-C. "Selective oxidation of hydrogen sulfide containing excess water and ammonia over Bi-V-Sb-O catalysts", Korean Journal of Chemical Engineering, 22(2), pp. 190-195 (2005).

12. Van Nisselrooya, P.F.M.T. and Lagasb, J.A. "Super claus reduces $\mathrm{SO}_{2}$, emission by the use of a new selective oxidation catalyst", Catalysis Today, 16, pp. 263-271 (1993).

13. Soriano, M.D., Cecilia, J.A., Natoli, A., JiménezJiménez, J., López Nieto, J.M., Rodríguez-Castellón, E. "Vanadium oxide supported on porous clay heterostructure for the partial oxidation of hydrogen sulphide to sulfur", Catalysis Today, 254, pp. 36-42 (2015).

14. Pi, J.H., Lee, D.-H., Lee, J.-D., Jun, J.H., Park, N.-K., Ryu, S.-O. and Lee, T.-J. "The study on the selective oxidation of $\mathrm{H}_{2} \mathrm{~S}$ over mixture $\mathrm{NaX}-\mathrm{WO}_{3}$ catalysts", Korean Journal of Chemical Engineering, 21, pp. 126131 (2004).

15. Bineesh, K.V., Kim, D.-K., Kim, D.-W., Cho, H.-J. and Park, D.-W. "Selective catalytic oxidation of $\mathrm{H}_{2} \mathrm{~S}$ to elemental sulfur over $\mathrm{V}_{2} \mathrm{O}_{5} / \mathrm{Zr}$-pillared montmorillonite clay", Energy \& Environmental Science, 3, pp. 302-310 (2010).

16. Bineesh, K.V., Kim, S.Y., Jermy, B.R. and Park, D.W. "Synthesis, characterization and catalytic performance of vanadia-doped delaminated zirconia-pillared montmorillonite clay for the selective catalytic oxidation of hydrogen sulfide", Journal of Molecular Catalysis A: Chemical, 308, pp. 150-158 (2009).

17. Bineesh, K.V., Kim, M.-I., Park, M.-S., Lee, K.Y. and Park, D.-W. "Selective catalytic oxidation of $\mathrm{H}_{2} \mathrm{~S}$ over $\mathrm{V}_{2} \mathrm{O}_{5}$-supported Fe-pillared montmorillonite clay", Catalysis Today, 175, pp. 183-188 (2011).

18. Moradi, M., Towfighi Daryan, J. and Mohamadalizadeh, A. "Response surface modeling of $\mathrm{H}_{2} \mathrm{~S}$ conversion by catalytic oxidation reaction over catalysts based on $\mathrm{SiC}$ nanoparticles using Box-Behnken experimental design", Fuel Processing Technology, 109, pp. 163-171 (2013).

19. Palma, V., Barba, D. and Ciambelli, P. " $\mathrm{H}_{2} \mathrm{~S}$ Removal in biogas by direct catalytic oxidation to sulphur on 
$\mathrm{V}_{2} \mathrm{O}_{5} / \mathrm{CeO}_{2}$ catalysts", Chemical Engineering Transactions, 29, pp. 631-636 (2012).

20. Jung, S.J., Kim, M.H., Chung, J.K., Moon, M.J., Chung, J.S., Park, D.W. and Woo, H.C. "Catalytic oxidation of $\mathrm{H}_{2} \mathrm{~S}$ to elemental sulfur over mesoporous $\mathrm{Nb} / \mathrm{Fe}$ mixed oxides", Studies in Surface Science and Catalysis, 146, pp. 621-624 (2003).

21. Bineesh, K.V., Kim, D.-K., Cho, H.-J. and Park, D.W. "Synthesis of metal-oxide pillared montmorillonite clay for the selective catalytic oxidation of $\mathrm{H}_{2} \mathrm{~S}$ ", Journal of Industrial and Engineering Chemistry, 16, pp. 593-597 (2010).

22. Keller, E., Ramani, S., Allison, D., Lusk, S., Hatcher, N., Swinney, L., Kirkendall, K., Torres, G., Stewart, P. and Pruitt, T. "Catalytic partial oxidation reaction zone, a temperature-control zones, Claus catalytic reaction zones, vapor-liquid sulfur separation zones, liquid sulfur outlets; configured to deter the accumulation of liquid sulfur in the Claus catalytic reaction zones", US Patent, 7,226,572 B1 (2007).

23. Mohamadalizadeh, A., Towfighi, J., Adinehnia, M. and Bozorgzadeh, H.R. " $\mathrm{H}_{2} \mathrm{~S}$ oxidation by multi-wall carbon nanotubes decorated with tungsten sulfide", Korean Journal of Chemical Engineering, 30, pp. 871877 (2013).

24. Mahshid, S., Askari, M. and Sasani Ghamsari, M. "Synthesis of $\mathrm{TiO}_{2}$ nanoparticles by hydrolysis and peptization of titanium isopropoxide solution", Journal of Materials Processing Technology, 189, pp. 296300 (2007).

25. Rezaee, M., Kazemeini, M., Rashidi, A.M. and Fattahi, M. "Preparation and evaluation of new nanocatalysts for selective oxidation of $\mathrm{H}_{2} \mathrm{~S}$ to sulfur", World Academy of Science, Engineering and Technology, 6, pp. 621-626 (2012).

26. López Ibáñez, R., Ramos Barrado, J.R., Martín, F., Brucker, F. and Leinen, D. "Oxide barrier coatings on steel strip by spray pyrolysis", Surface and Coating Technology, 188-189, pp. 675-683 (2004).

27. Martin, M.I., Rabanal, M.E., Gomez, L.S., Torralba, J.M. and Milosevic, O. "Microstructural and morphological analysis of nanostructured alumina particles synthesized at low temperature via aerosol route", Journal of the European Ceramic Society, 28(13), pp. 2487-2494 (2008).

28. Novaković, T., Radić, N., Grbić, B., Marinova, T., Stefanov, P. and Stoychev, D. "Oxidation of $n$-hexane over $\mathrm{Pt}$ and $\mathrm{Cu}-\mathrm{Co}$ oxide catalysts supported on a thin-film zirconia/stainless steel carrier", Catalysis Communications, 9, pp. 1111-1118 (2008).

29. Rashidi, A.M., Akbarnrjad, M.M., Khodadadi, A.A., Mortazavi, Y. and Ahmadpour, A. "Single-wall carbon nanotubes synthesized using organic additives to CoMo catalysts supported on nanoporous MgO", Nanotechnology, 18, pp. 315605-315609 (2007).

30. Fattahi, M., Kazemeini, M., Khorasheh, F. and Rashidi, A. "Kinetic modeling of oxidative dehy- drogenation of propane (ODHP) over a vanadiumgraphene catalyst: Application of the DOE and ANN methodologies", Journal of Industrial and Engineering Chemistry, 20(4), pp. 2236-2247 (2014).

31. Lazic, Z.R., Design of Experiments in Chemical Engineering: A Practical Guide, 1st Edition, Wiley-VCH (2004).

32. Fattahi, M., Kazemeini, M., Khorasheh, F. and Rashidi, A.M. "Morphological investigations of nanostructured $\mathrm{V}_{2} \mathrm{O}_{5}$ over graphene used for the ODHP reaction: From synthesis to physiochemical evaluations", Catalysis Science and Technology, 5(2), pp. 910-924 (2015).

33. Fattahi, M., Kazemeini, M., Khorasheh, F. and Rashidi, A.M. "Vanadium pentoxide catalyst over carbon-based nanomaterials for the oxidative dehydrogenation of propane", Industrial \& Engineering Chemistry Research, 52, pp. 16128-16141 (2013).

34. Kim, J.H., Jung, K.Y., Park, K.Y. and Cho, S.B. "Characterization of mesoporous alumina particles prepared by spray pyrolysis of $\mathrm{Al}(\mathrm{NO}-3)_{2} .9 \mathrm{H}_{2} \mathrm{O}$ precursor: Effect of CTAB and urea", Microporous and Mesoporous Materials, 128, pp. 85-90 (2010).

35. Novaković, T., Radić, N., Grbić, B., Dondur, V., Mitrić, M., Randjelović, D., Stoychev, D. and Stefanov, P. "The thermal stability of porous alumina/stainless steel catalyst support obtained by spray pyrolysis", Applied Surface Science, 255, pp. 30493055 (2008).

36. Connock, L. "Approaching the limit: $99.9 \%$ sulphur recovery", Sulphur, 257, pp. 34-55 (1998).

37. Golestani, F., Kazemeini, M., Fattahi, M. and Amjadian, A. "Optimum operating conditions for direct oxidation of $\mathrm{H}_{2} \mathrm{~S}$ in a fluidized bed reactor", World Academy of Science, Engineering and Technology, 77, pp. 411-415 (2011).

38. Yasyerli, S., Dogu, G., Ar, I. and Dogu, T. "Dynamic analysis of removal and selective oxidation of $\mathrm{H}_{2} \mathrm{~S}$ to elemental sulfur over $\mathrm{Cu}-\mathrm{V}$ and $\mathrm{Cu}-\mathrm{V}$-Mo mixed oxides in a fixed bed reactor", Chemical Engineering Science, 59, pp. 4001-4009 (2004).

39. Rashidi, F., Sasaki, T., Rashidi, A.M., Nemati Kharat, A. and Jafari Jozani, K. "Ultradeep hydrodesulfurization of diesel fuels using highly efficient nanoaluminasupported catalysts: Impact of support, phosphorus, and/or boron on the structure and catalytic activity", Journal of Catalysis, 299, pp. 321-335 (2013).

40. Rezaee, M. "Preparation of Claus nanocatalyst for replacing the commercial catalysts", MSc Thesis, Sharif University of Technology (2011).

\section{Biographies}

Mohammad Rezaee obtained his BS and MS degrees in Chemical Engineering from the Department of Chemical and Petroleum Engineering at Sharif Uni- 
versity of Technology, Tehran, Iran. His research interests include catalysts preparation, characterization and evaluation in the field of chemical engineering.

Mohammad Kazemeini is professor of Chemical and Petroleum Engineering at Sharif University of Technology, Iran. His current research interests include nanocatalysts (mostly CNT and CNF based) preparation, characterization and evaluation in the field of chemical engineering and petroleum refining.

Moslem Fattahi obtained his BS degree in Chemical Engineering in 2006 from Razi University, Kermanshah, Iran, and his MS and PhD degrees in 2008 and 2013, respectively, from the Department of Chemical and Petroleum Engineering at Sharif University of Technology, Tehran, Iran. His main research inter- ests include process modeling, reaction engineering, catalysts preparation, characterization and evaluation in the field of chemical engineering and petroleum refining.

Ali Morad Rashidi is Associate Professor of Chemical Engineering at Research Institute of Petroleum Industry (RIPI), Tehran, Iran. His main research interests include nano-materials (mostly CNT, CNF, and graphene based) preparation, characterization, and evaluation in the field of chemical engineering.

Leila Vafajoo is Associate Professor of Chemical Engineering at Islamic Azad University, Tehran South Branch, Tehran, Iran. Her main research interests include process modeling and environmental engineering in the field of chemical engineering. 